\title{
POGOVOR \\ O SAMOMORU
}

Praktični priročnik za pogovor

o najtežjih življenjskih vprašanjih

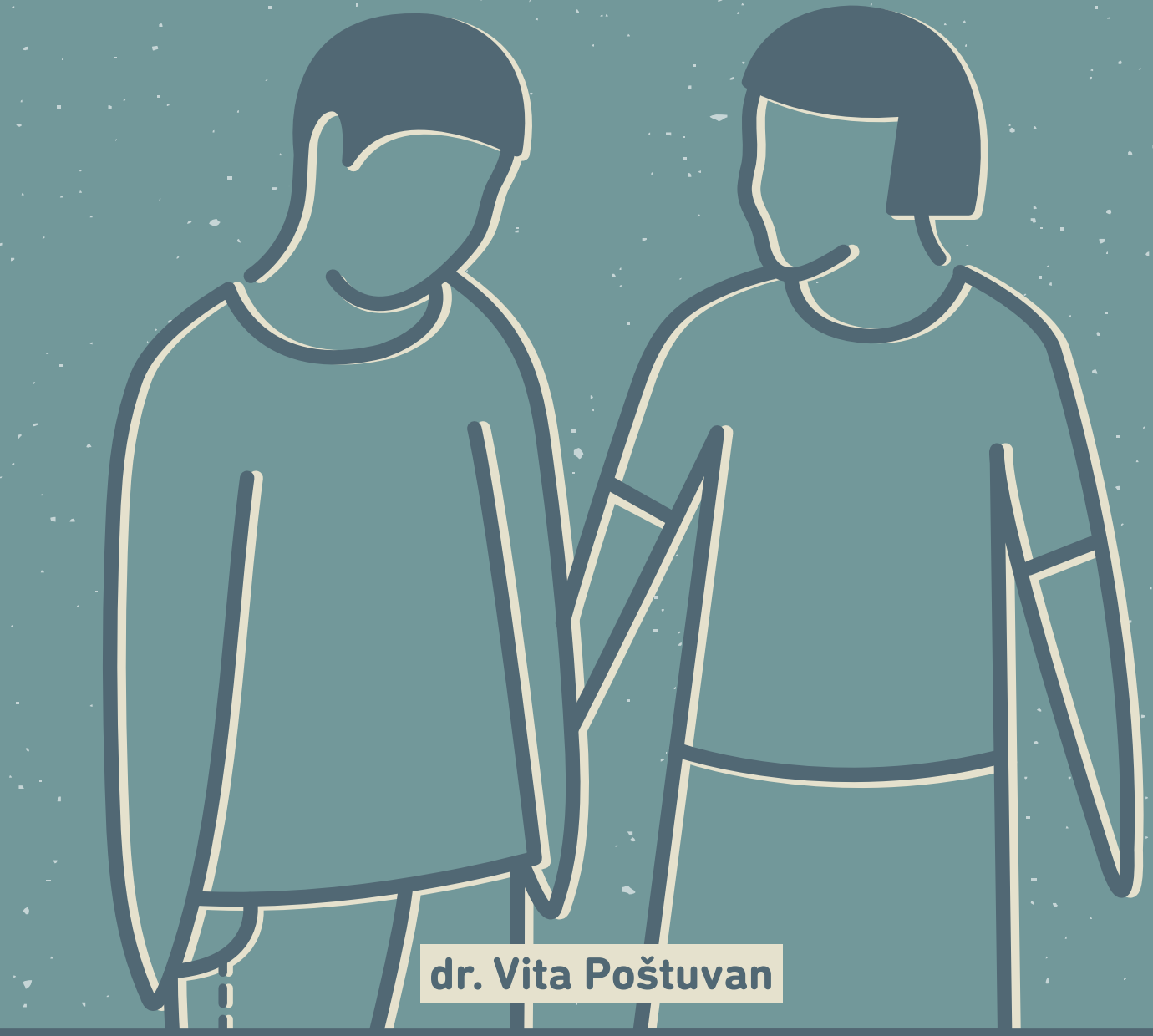





\section{Vita Poštuvan}

\section{POGOVOR O SAMOMORU Praktični priročnik za pogovor o najtežjih življenjskih vprašanjih}


Pogovor o samomoru: praktični priročnik za pogovor o najtežjih življenjskih vprašanjih Vita Poštuvan

Strokovni pregled: Diego de Leo in Tina Podlogar

Lektoriranje: Davorin Dukič

Oblikovanje: Polonca Peterca

Izdala in založila: Založba Univerze na Primorskem

Titov trg 4, Koper

www.hippocampus.si

Glavni urednik: Jonatan Vinkler

Vodja založbe: Alen Ježovnik

ISBN 978-961-7055-90-0 (spletna izdaja: pdf)

http://www.hippocampus.si/ISBN/978-961-7055-90-0.pdf

ISBN 978-961-7055-91-7 (spletna izdaja: html)

http://www.hippocampus.si//SBN/978-961-7055-91-7/index.html

DOl: https://doi.org/10.26493/978-961-7055-90-0

Koper, 2020

(c) 2020 Univerza na Primorskem

Izdajo je sofinancirala Agencija za raziskovalno dejavnost (projekt J5-8244).

(c) $(7)(\mathrm{EY})$

Kataložni zapis o publikaciji (CIP) pripravili v Narodni in univerzitetni knjižnici v Ljubljani

COBISS.SI-ID $=303383552$

ISBN 978-961-7055-90-0 (pdf)

ISBN 978-961-7055-91-7 (html) 


\section{KAZALO}

Stiska, ne izbira

Različni odzivi

Če stisk ne rešujemo ...

Zaupati stisko drugi osebi

Prepoznati hudo stisko

Prepoznati samomorilni proces

Misli o samomoru in namere

Pes, ki laja, ne grize

Koraki za pogovor

1. korak ukrepanja: priprava

2. korak ukrepanja: vprašati

3. korak ukrepanja: pogovarjanje

4. korak ukrepanja: odnos zaupanja

5. korak ukrepanja: napotitev in krog podpore

Nujni primeri

Telefonski klic

Doživljanje ob nudenju podpore

Skrb zase pri podpori drugim

Kam po pomoč?

Upad samomorilnega vedenja

Pojasnilo zgodbe iz življenja 



\section{STISKA, NE IZBIRA}

Stiske so normalen del naših življenj.

Stiske se povečajo ob večjih življenjskih dogodkih, kot so: selitve, spremembe $v$ družinskih ali partnerskih razmerjih, menjava ali izguba službe oz. finančne varnosti, izguba ali smrt bližnje osebe, nesreča ali bolezen in druge težave.
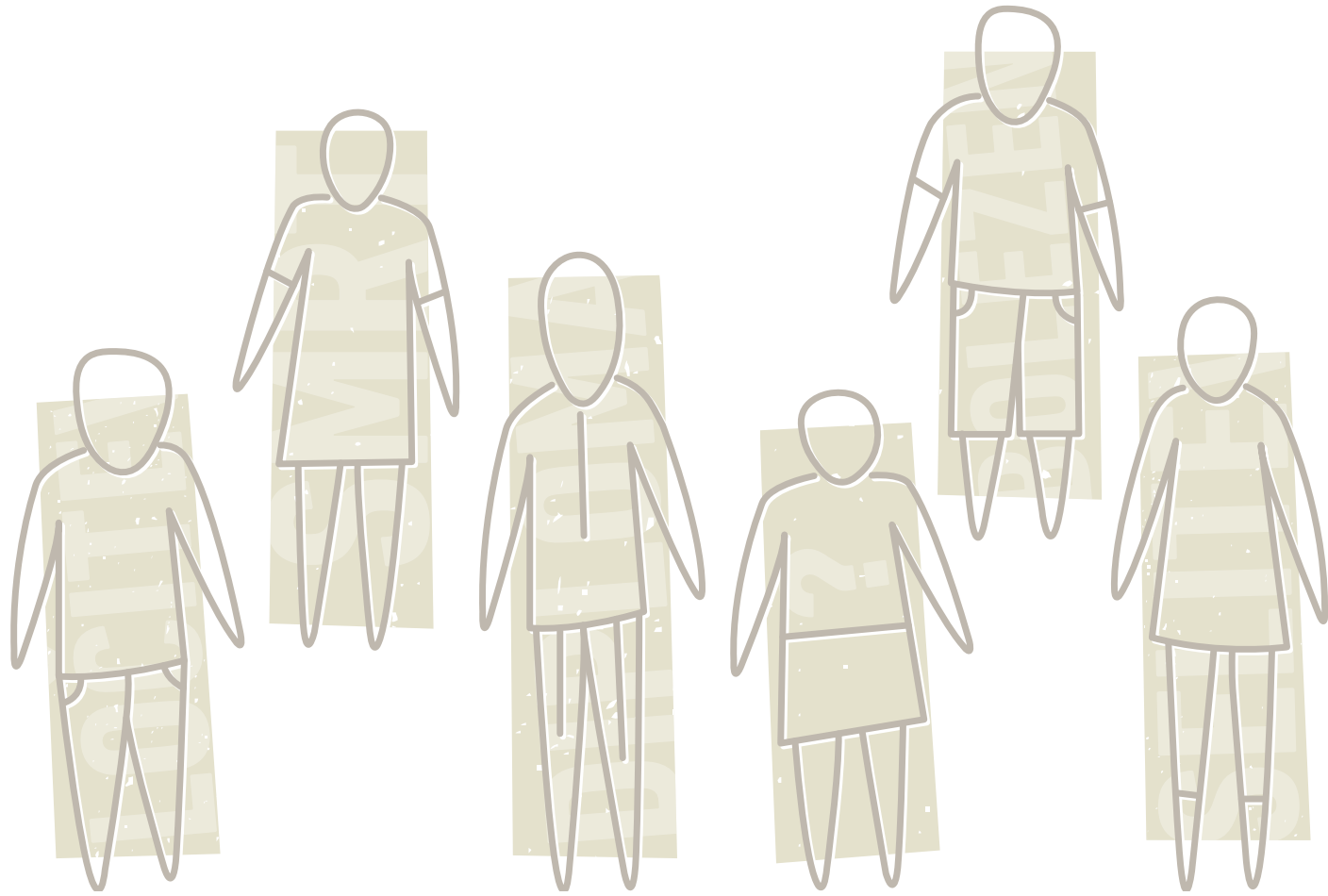

Nekatere se kažejo v obliki vsakodnevnih stresorjev, ki so lahko:

negativni (npr. usklajevanje

številnih obveznosti med delom in osebnim življenjem) pozitivni (npr. razmišljanje, kako

najboljše pripraviti rojstnodnevno presenečenje za bližnje) 


\section{RAZLIČNI ODZIVI}

Ljudje se različno odzivamo na različne vrste situacij oz. stisk. V skladu z evolucijskim razvojem je to največkrat $z$ bojem, begom ali tako, da obstojimo oz. zamrznemo. Primerov iz vsakdanjega življenja je veliko.
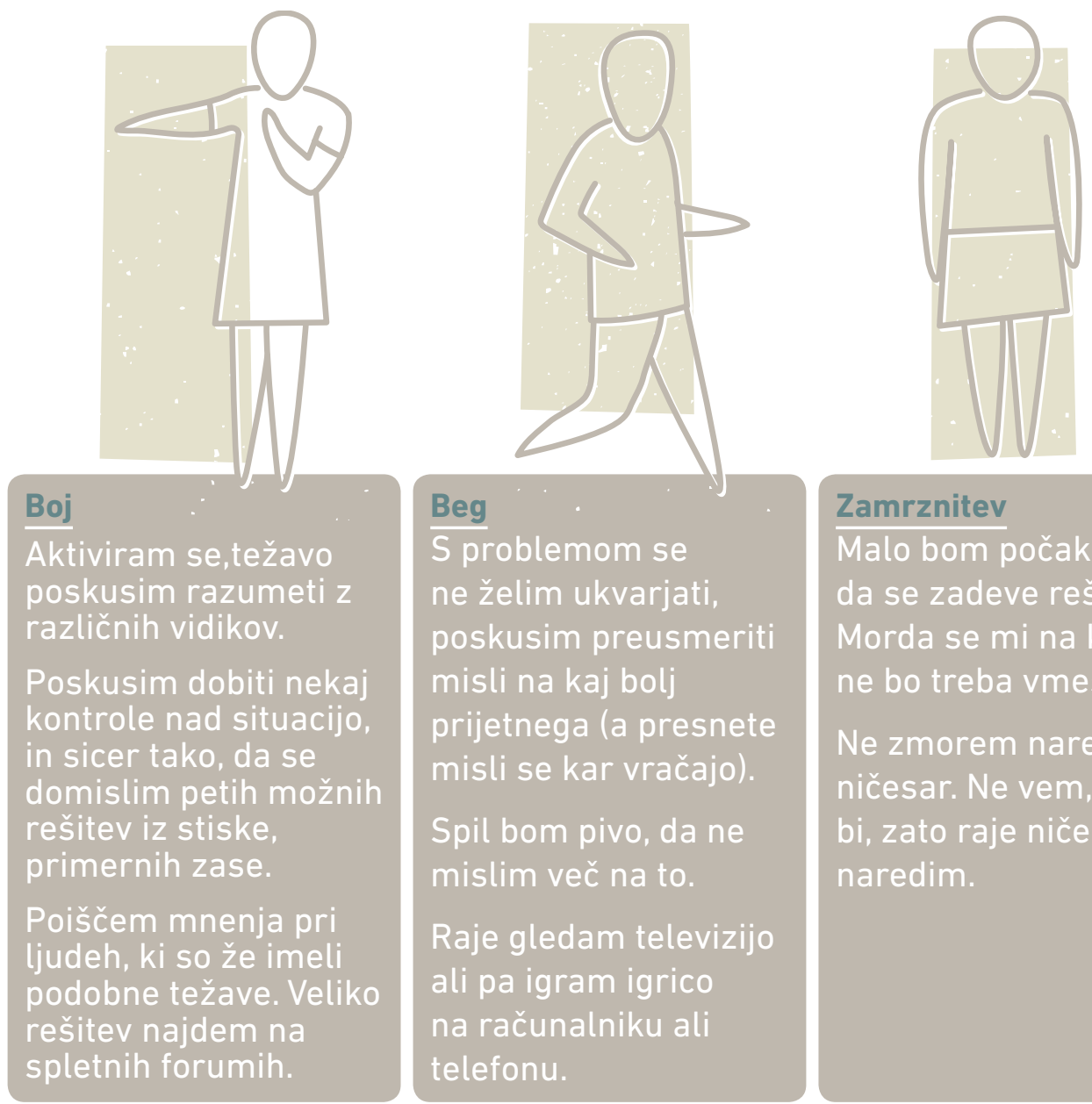

Zamrznitev

Malo bom počakal, da se zadeve rešijo. Morda se mi na koncu ne bo treba vmešavati.

Ne zmorem narediti ničesar. Ne vem, kaj bi, zato raje ničesar ne naredim.

Pri sebi lahko tako opazite razliko $v$ tem, koliko vas različne situacije vržejo iz tira oz. koliko se lahko z njimi konstruktivno (tj. uspešno) soočite. 


\section{ČE STISK NE REŠUJEMO ...}

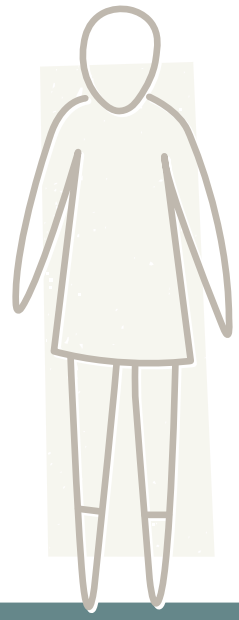

morda izzvenijo.

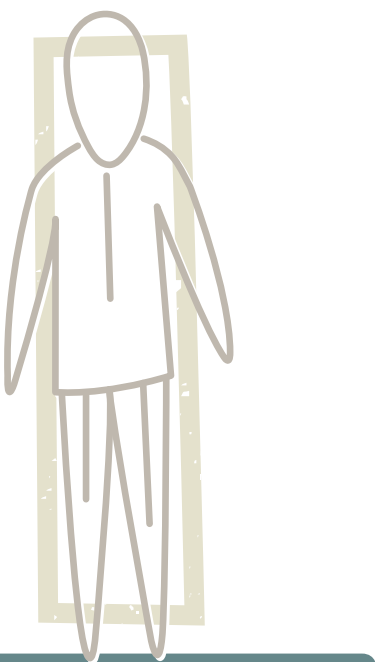

mogoče daljše obdobje ostanejo enake in se nanje navadimo.

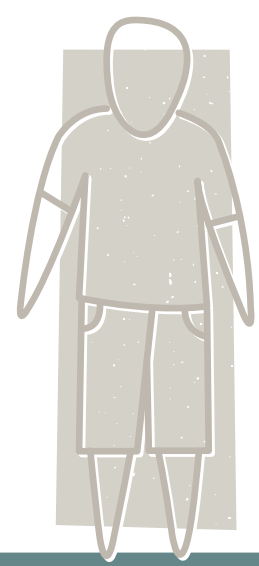

... se lahko poglobijo

v večjo osebno stisko.

Težava nastane, ko imamo občutek, da:

stiske ne moremo rešiti in lahko pri tem občutimo nemoč. ni rešitve za naš problem, pri tem lahko občutimo brezup.

V takšnih okoliščinah so pogosta tudi čustva žalosti, jeze, negotovosti, apatičnosti, odtujenosti in podobno.

Stiske so lahko pomemben sprožilec težav na področju duševnega zdravja, posebno depresije, tesnob, zlorabe substanc, drugih nezdravih vedenj ali tudi samomorilnega vedenja. 


\section{ZAUPATI STISKO DRUGI OSEBI}

Kadar stisko zaupamo drugi osebi, imamo možnost, da se razbremenimo, dobimo podporo, nove zamisli za reševanje položaja ali za spreminjanje svojega odnosa do težave. Z zaupanjem resda razkrivamo svoje težave, negotovosti, ranljiv del sebe, tvegamo razočaranja, obenem pa nas ravno to resnično povezuje z drugimi in krepi naše odnose. Koliko in komu zaupamo, je odvisno od posameznika, nekaj razlik pa je tudi glede na spol.

Za ženske je eden od dejavnikov, ki varuje pred težavami na področju duševnega zdravja, to, da imajo skupino dobrih prijateljic, ki jim lahko iskreno zaupajo svoje težave.

Za moške je eden od dejavnikov, ki varuje pred težavami na področju duševnega zdravja, to, da imajo eno osebo, navadno žensko, ki ji lahko iskreno zaupajo svoje težave.

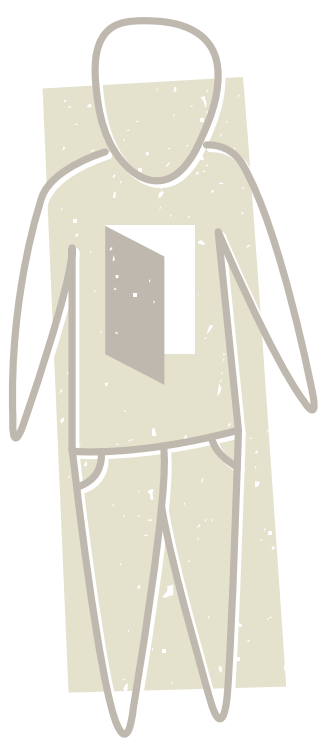

Zaradi slabih izkušenj ljudje včasih menijo, da drugim ne smemo zaupati vsega. Tudi za odraščajoče mlade je največja ovira za iskanje pomoči v stiski prav prepričanje, da morajo biti avtonomni in sami rešiti svoje težave. Kadar je stiska tako huda, da oseba že razmišlja o samomoru, bo svoje težave še težje zaupala drugim. Intuitivno bi sicer sklepali, da bo ravno resnost položaja sprožila hitrejše iskanje pomoči, pa to pogosto preprečujeta sram ali prepričanje: „Če razmišljam o smrti/samomoru, to pomeni, da je $z$ mano že vse narobe in mi ni več pomoči.« 


\section{PREPOZNATI HUDO STISKO}

Včasih je težko prepoznati, da je oseba $v$ hudi stiski. Kot zunanji opazovalec namreč težko z gotovostjo vemo, kaj oseba misli ali čuti, zato se lahko zanašamo zgolj na sklepanje na podlagi tega, kar nam nekdo pove, ali posamezne znake razberemo iz vedenja.

Največkrat lahko stisko prepoznamo po tem, da se začne oseba drugače obnašati, kot se je sicer. To pomeni, da moramo prepoznati spremenjeno vedenje, razpoloženje ali druge znake.

V nekaterih okoliščinah spremembe še težje prepoznamo. Pri otrocih in odraščajočih mladostnikih, ki se novih vedenj šele učijo, je težko razločiti, kdaj so spremembe nekaj normalnega (normativnega) in pričakovan del zorenja, kdaj pa kažejo na stisko ter opozarjajo, da z osebo nekaj v redu. Prav tako so spremembe normalen del nekaterih življenjskih dogodkov, včasih so tudi majhne in subtilne (torej težko opazne).

Zato sprememb v vedenju pogosto ne prepoznamo kot opozorilnih znakov in/ali razloge zanje napačno pripišemo zunanjim okoliščinam.
Spremembe, na katere bodimo

pozorni.

Opazno spreminjanje razpoloženja.

Občutljivost in depresivno

razpoloženje

Izražanje občutkov obupa

Znaki tesnobe, vključno s povečanim nemirom

Izražanje občutkov ujetosti in nemoči

Pogosto menjavanje razpoloženja

Težave na miselnem področju

Nizka samopodoba, občutek

ničvrednosti

Nenadne spremembe v vedenju

Povečana zloraba alkohola in drog oz. poslabšanje po obdobju abstinence

Umik iz socialnih stikov s prijatelji

in družino (občutki odtujenosti, biti v breme)

Neobičajno izražanje jeze,

nerazumljiva jeza, agresivnost,

cinizem, impulzivnost in razdražljivost

Opustitev dejavnosti, ki so osebo

navadno veselile

Pomanjkanje motivacije in ciljev

Slabša koncentracija in težave v miselnih procesih 


\section{PREPOZNATI \\ SAMOMORILNI PROCES}

\section{Pri samomorilnem vedenju govorimo o procesu, ki poteka od misli do vedenj. Ta proces ni nujno linearen in se pri vsakem posamezniku odvija malo drugače.}

\section{RAZMIŠLJANJE O SMRTI}

»Najlažje bi bilo, če se sploh ne bi več zbudil.«

MISLI O SAMOMORU

»Najlažje bi bilo, če bi se ubil.«

\section{SAMOMORILNI NAMEN}

»Nameravam narediti samomor.«

\section{SAMOMORILNI NAČRT}

»Vem kje, kako in kdaj bom naredil samomor.«

\section{POSKUS SAMOMORA}

\section{SAMOMOR}

Samomorilni proces je navadno posledica nekaj časa trajajoče hude stiske. Pogosto se začne z občutki nemoči in pasivno željo, da oseba ne bi več živela.

Če se položaj ne izboljša, se lahko proces stopnjuje do misli, namenov, načrta in nato poskusa ali smrti zaradi samomora. Proces se lahko vedno ustavi.

Želje, misli in namen je težko razbrati iz vedenja, zato moramo o njih vprašati. Načrtovanje samomora je včasih možno prepoznati, ker se oseba pripravljanja na dejanje in morda zbira informacije, metodo ali pa se dogajajo druge nenavadnosti, preko katerih lahko dobimo vpogled $v$ razmišljanje in počutje. 


\section{MISLI O SAMOMORU IN NAMERE}

Resne misli o samomoru in namere za dejanje se navadno izrazijo v vedenju in besedah.

\section{Vedenja:}

Nevarno in tvegano vedenje.

Opuščanje (najljubših) aktivnosti.

Umikanje v samoto.

Poslavljanje od prijateljev, družine.

Razdajanje dragocene lastnine.

Urejanje osebnih in poslovnih zadev.

Nenadno zanimanje za verske obrede ali njihova opustitev.

Načrtovanje pogreba.

Preokupiranost s smrtjo in z umiranjem.

Priprava pripomočkov za samomor. Prejšnji poskusi samomora.

Nenavadne spremembe (tudi navidezno izboljšanje razpoloženja). lzjave, ki posredno nakazujejo željo po smrti:

Utrujen sem od življenja, ne morem več naprej.

Moji družini bi bilo bolje brez mene.

Saj ne bi bilo nikomur mar, če me ne bi bilo več.

Le stran hočem.

Kmalu me ne bo več.

Kmalu ti ne bo več treba skrbeti zame.

lzjave, ki neposredno nakazujejo željo po smrti:

Odločil sem se, da se bom ubil. Želim si, da bi bil mrtev.

Naredil bom samomor.

Vse bom končal.

Če se (nekaj) ne bo zgodilo, se bom ubil. 


\section{PES, KI LAJA, NE GRIZE}

Pri preprečevanju samomora pogosto naletimo na prepričanje, da tisti, ki govorijo (ali celo grozijo), da bodo naredili samomor, tega gotovo ne bodo storili.

To prepričanje ne drži, saj so za večino ljudi, ki so umrli zaradi samomora, po smrti ugotavljali, da so $v$ preteklosti izrazili, da razmišljajo o samomoru.

Res pa je tudi, da ljudje čisto običajno izrečemo marsikaj, kar ni mišljeno dobesedno. Glede samomora je takšnih besednih zvez precej (npr. oseba v neprijetnem položaju reče, da bi raje umrla, kot bila zdaj v teh okoliščinah), zato je resnično težko ločiti, kdaj gre za resno situacijo, kdaj pa le za način govora ali izražanja nelagodja.

Vedno pa je boljše vsako pripombo vzeti resno, saj tako ne obžalujemo, da morda nismo prepoznali težkega položaja sočloveka.

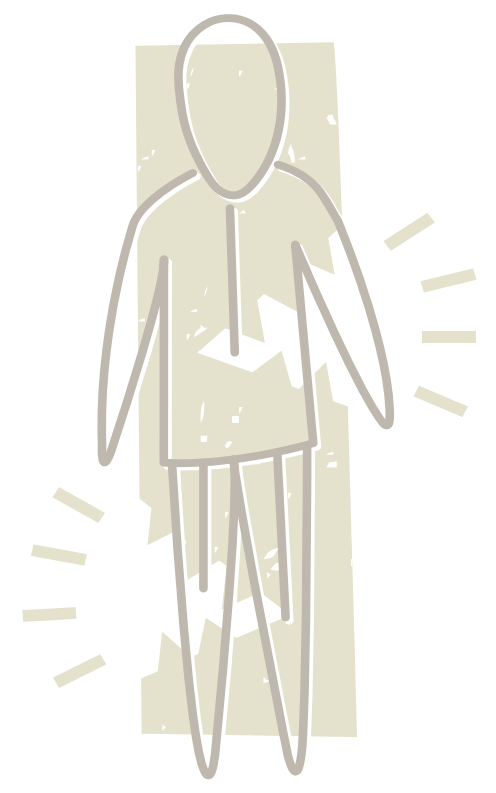

Prepoznava, da bi nekdo lahko bil

v hudi stiski, predstavlja predpogoj

za pogovor o samomorilni stiski.

Tak pogovor navadno predstavlja težko okoliščino, saj laiki (pa tudi strokovnjaki) pogosto ne vedo, kako naj ravnajo. Odziv bo odvisen od izkušenj, stališč, ozaveščenosti osebe in drugih okoliščin. Koraki za pogovor so vam lahko v pomoč. 


\section{KORAKI ZA POGOVOR}

Za pogovor o najtežjih življenjskih vprašanjih si lahko pomagamo s koraki:

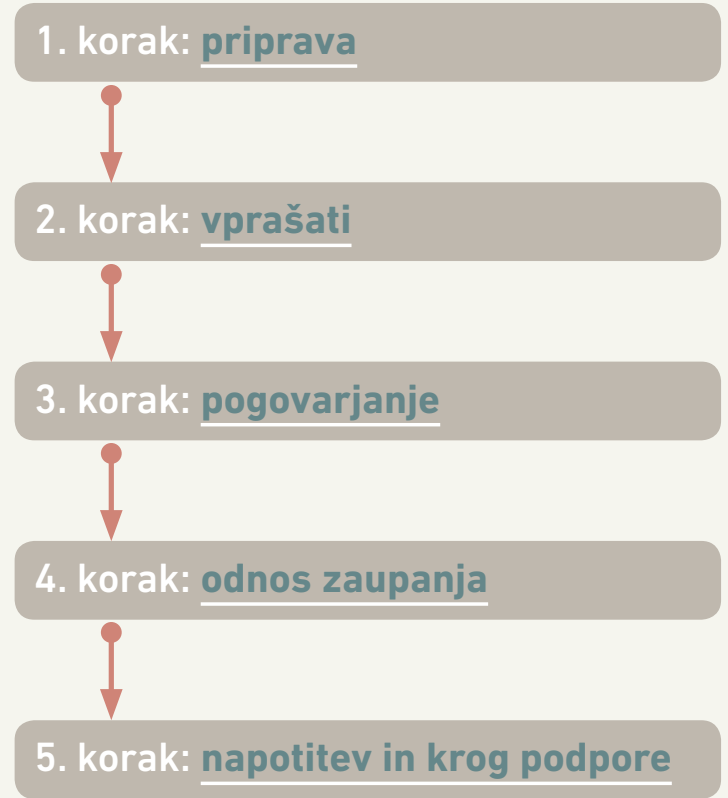

Koraki vam lahko služijo kot okvir, kako temo nasloviti. Ne obremenjujte se s točnim vrstnim redom ali s tem, da mora biti rezultat vašega pogovora takoj viden. Ključno je, da skozi te korake z osebo v stiski zgradite topel in iskren odnos. 


\section{KORAK UKREPANJA: PRIPRAVA}

Kadar se vam zdi, da je nekdo v hudem življenjskem položaju ali morda v stiski, s katero se ne zna uspešno soočiti, lahko najbolj pomagamo $z$ iskrenim in toplim odnosom, ki ga zgradimo $z$ osebo. Tak odnos vključuje sočutje in razumevanje ter daje občutek, da nam obstoj te osebe $v$ našem življenju nekaj pomeni.

Pogovori o najtežjih življenjskih vprašanjih (mednje sodijo vprašanja o samomorilnih težnjah) niso preprosti. Če je možno, se poskusimo na takšen pogovor pripraviti, npr. tako, da si vzamemo čas, najdemo primeren prostor, poskrbimo, da nas v tem času drugi ne motijo. Pogosto se seveda zgodi, da se taki pogovori zgodijo nenačrtovano, kar jim $v$ naših življenjih daje posebno mesto.

Včasih se lažje iskreno pogovarjamo ob skupnih aktivnostih, npr. ob kartanju ali sprehodu. Posebno za moške je namreč lažje, če ima pogovor zaradi aktivnosti tudi zunanji okvir. 


\section{IZ ŽIVLJENJA}

Že nekaj tednov sem opazoval, da je Tone prav pošteno »tečen«. Ves čas je bil nekoliko slabše volje, godrnjal je nad vsem. Sicer ni bil tak po naravi, prav nasprotno, pogosto je držal vse pokonci s svojo dobro voljo.

Potem smo imeli ravno v tistem času službeno zabavo. Razmišljal sem, da moram izkoristiti to priložnost in se malo podružiti z njim. In res smo kar en čas sproščeno klepetali z njim in skupino sodelavcev. Kakšno urco je bil še dobre volje, pred drugimi tudi ni pokazal, da bi ga karkoli mučilo in mislil sem že, da je vse skupaj v moji glavi, da pretiravam s skrbmi. Potem pa se je čez čas umaknil na samo in kar nekaj časa gledal $v$ svoj telefon.

Tuhtal sem, ali naj grem do njega ali ne. Najraje ne bi, saj nisem imel izbranih besed. Ampak sem vedel, da bo verjetno težko najti drugo priložnost. 


\section{KORAK UKREPANJA: PRIPRAVA}

Poleg načrtovanja prostora in časa za pogovor je priporočljivo premisliti tudi naše odzive ob pogovoru o samomorilni stiski, zato je dobro:

- izbrati besede, ki bi jih lahko uporabili;

- premisliti, katera čustva bomo najverjetneje občutili, če nam nekdo pove, da razmišlja o samomoru;

- imeti pripravljenih tudi nekaj idej, kako lahko pomagamo osebi;

- imeti seznam načinov in oseb, ki bi lahko še pomagali.

Včasih je dobro premisliti, kakšni so naši načini odzivanja, saj lahko nekateri besedni in nebesedni znaki komunikacijo spodbujajo ali pa jo zavirajo.

Zelo pogosto je, da v takšnih pogovorih doživljamo občutke strahu, negotovosti (npr. kaj reči, kako bo oseba reagirala), žalosti, nemoči, morda tudi jeze (ali nase, da že nismo prej ukrepali, ali na drugo osebo, da ni že prej poiskala pomoči), krivde, včasih tudi olajšanja (da končno naslovimo to temo ali da nam oseba zaupa). Taka čustva so navadno tudi zelo intenzivna. Neugodna intenzivna čustva so pogosto razlog, da se pogovoru o samomoru izogibamo, saj jih je težko preseči. 


\section{IZ ŽIVLJENJA}

Pomislil sem, da sem verjetno edini, ki si ga upam vprašati, kako se počuti.

Sam sem bil dobro razpoložen, zato sem mu lahko priskočil na pomoč. Vedel sem, da mi ne bo ravno lahko, če mi bo res povedal, da je nekaj narobe, ampak moral sem mu ponuditi pomoč. Srce mi je razbijalo, čutil sem čuden cmok $v$ grlu. Ampak moja izkušnja iz otroštva, ko se je stric zapil do konca, mi je narekovala, da naj vsega ne opazujem le od daleč.

Če bo tako težko, bom pa poklical reševalce, sem razmišljal. 


\section{KORAK UKREPANJA: VPRAŠATI}

Namen vaše intervencije je spodbujanje pogovora. Glavno vodilo pri postavljanju vprašanj mora biti, da ne smejo obsojati, ampak je potrebno z njimi usmerjati in dodatno motivirati pripovedovanje osebe. $S$ tem namreč gradite odnos z osebo. To je še posebno pomembno, ko človeka ne poznate.

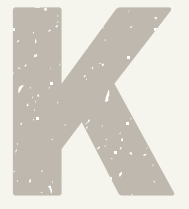

Pomagajo nam lahko odprto postavljena vprašanja (tista, ki se začnejo s črko k), npr.: Kako vidite to ...? Kdaj je težje ...? Kakšne načine reševanja ste že ubrali ...? Kako mi lahko opišete položaj ...?

V pomoč so lahko tudi neverbalni znaki, ki spodbujajo pripovedovanje - tudi trenutki tišine, ko lahko oseba zbere misli.

Namen pogovora ni, da osebi na hitro podate nekaj nasvetov za boljše življenje, temveč, da ji dovolite, omogočite, da sama razmišlja o svojih težavah in preko tega najde rešitve. $\mathrm{S}$ takim pogovorom lahko dobi vpogled $v$ povezavo med samomorilnimi težnjami in dogodki v življenju.

Obenem je pomembno, da s pogovorom gradimo most do razumevanja osebe in ustvarjamo čustveno vez, ki daje podporo. Morda en pogovor ne bo dovolj za rešitev celotne situacije, a bo posamezniku v stiski dal sporočilo, da s svojimi težavami ni sam. Oseba tako dobi občutek sprejemanja in podpore, kar je prvi korak k okrevanju.

Ker je tak pogovor težek tudi za osebo v stiski, se mu bo morda tudi izogibala. Bodite vztrajni. Morda lahko rečete: »Razumem, da zdaj zate ni pravi trenutek za tak pogovor. Prosim te, če ga lahko nadaljujeva kmalu/čez nekaj trenutkov.« 


\section{IZ ŽIVLJENJA}

Stopil sem do njega. »Tone, zdi se mi, da si zadnje čase malo spremenjen. Kaj se ti dogaja?« sem rekel.

Takoj me je postalo strah, da sem naredil nekaj narobe, saj se mu je obraz popolnoma skremžil in že sem hotel izstreliti, da bo že kmalu vse boljše, da naj se ne sekira za nič.

Potem sem se spomnil nasveta, da bom s preprostimi besedami in tišino spodbudil pogovor ... »Daj, povej mi, kako si ... « sem počasi rekel in počakal, da je Tone začel govoriti. 


\section{KORAK UKREPANJA: VPRAŠATI}

Vprašati po samomorilnih mislih je zagotovo težko.

Takšno vprašanje lahko:

- sledi daljšemu pogovoru, ko se morda le za hip zazdi, da se z osebo dogaja nekaj več kot le soočanje $z$ običajnimi življenjskimi težavami. Oseba lahko dlje časa govori o težavah, subtilni znaki pa se lahko pokažejo skozi občutke brezupa in nemoči;

- postavimo tudi brez daljšega uvoda v pogovoru. Praviloma je to takrat, ko okoliščine že poznamo ali pa so znaki očitenejši. Na ta način lahko ključna vprašanja naslovimo neposredneje.

V pogovoru vedno raziskujemo samomorilni proces, pri tem pa ne pozabimo: samomorilni proces je mogoče ustaviti! 


\section{IZ ŽIVLJENJA}

Tone je imel kaj za povedati. Sploh nisem razumel, kako je mogoče, da se mu je pod navadno veselim obrazom nabiralo tako veliko stvari. Toliko bolečine in skritih čustev.

Že več let je imel težave $v$ zvezi, v zadnjem tednu pa je dobil še nekaj slabih novic glede svojega zdravja. Pravzaprav so to stvari, ki so nam vsem znane, ampak videl sem, da so naenkrat zanj postale glavna preokupacija.

Vse se je vrtelo okrog tega, kako bo rešil svojo zvezo. Sploh ni več počel ničesar drugega kot premleval te stvari. Hkrati pa je že popolnoma obupal nad tem, da so kakšne spremembe sploh možne in se mu je zdelo, da vse - tudi življenje - polzi iz njegovih rok. 


\section{KORAK UKREPANJA: VPRAŠATI}

Za naslavljanje samomorilnega vedenja lahko uporabite bolj ali manj neposreden pristop. Pri obeh lahko uporabite uvod v pogovor. Boljše je, če so vprašanja v sedanjiku (namesto »Ste že kdaj pomislili na samomor? « uporabite »Ali zdaj razmišljate o samomoru? «), sicer bodo odgovori presplošni in preveč nerelevantni za ta trenutek.

\section{Manj neposredno}

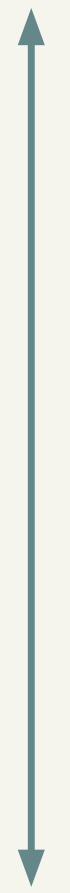

\section{Bolj neposredno}

»Ali kdaj opaziš, da si želiš, da bi lahko zaspal in se ne bi nikdar zbudil?«

»Ko so ljudje v taki stiski, kot si zdaj ti, si velikokrat želijo, da bi bili mrtvi. Se tudi ti tako počutiš?«

»Zadnje čase se mi zdiš žalosten, včeraj sem te slišal reči, da nisi več prepričan, da lahko nadaljuješ. Ko pridemo v takšno obdobje, se nam lahko zdijo stvari brezupne.

Zanima me, ali si morda razmišljal, da bi si vzel življenje?«

»Ali v zadnjem tednu/času razmišljaš o tem, da bi si vzel življenje?«

»Zdiš se mi zelo nesrečen. Ali razmišljaš o samomoru?«

Vsekakor izberite tiste besede, ki vam bodo blizu. Pomembno je, da ste v pogovoru pristni. 


\section{IZ ŽIVLJENJA}

Med pripovedovanjem je malo postal.

»Kako težko ti je trenutno?«

»Hudo je, prekleto hudo. Boli me duša, boli me telo;

po moje sem še zbolel zato."

»Je kdaj tako hudo, da razmišljaš o samomoru,

Tone?«

»Ja.«

Pogled je usmeril v tla. 


\section{KORAK UKREPANJA: VPRAŠATI}

Pogovor o samomoru in stiskah za nekoga, ki razmišlja o samomoru, zagotovo ni preprost. Morda bo potrebne nekaj vztrajnosti, da se bo sogovornik odprl in odkrito spregovoril. Dober, sočuten odnos do osebe in njenih težav bo dobra spodbuda za pogovor, saj daje občutek varnosti.

Pri pogovoru se ne izogibajmo besedi samomor. Uporaba te besede osebi $v$ stiski sporoča, da je nekdo slišal klic na pomoč. Mit, da bomo nekoga s tem vprašanjem spodbudili k samomorilnim mislim, je napačen. Tisti, ki o samomoru ne razmišlja, nam bo to tudi naravnost povedal, in s tem ne bomo naredili nobene škode. Zaupanje osebe, ki je sicer v stiski, vendar pa ne razmišlja o samomoru, v nas se lahko še poveča, če vidi, da smo brez zadržkov pripravljeni govoriti tudi o tem.

Izogibajte se vprašanjem, ki so obsojajoča, npr.:

»Saj ne razmišljaš o samomoru, kajne?"

»Saj ne bi naredil/-a česa neumnega, a ne?»

»Samomor je res neumna ideja. Prav gotovo nisi pomislil/-a na to?« 


\section{IZ ŽIVLJENJA}

Tonetov pogled je kar nekaj časa motril špranje $v$ betonu, iz katerih je gnala trava. Pogledoval sem proti travi in proti njemu in nekaj časa kar molčal. Mislim, da je imel občutek, da sem mu dal nekaj trenutkov, da je zbral misli. »Povej mi kaj več, « sem počasi dodal.

»Ja. Samomor. To je tako, a veš ... Ves čas mi hodi po glavi, da bi bilo najboljše, če me ne bi bilo. Verjetno se itak to vidi in se vsi že norca delajo iz mene."

»Ah, nihče niti pomisli ne, da bi se norčeval. Fantje $v$ ekipi se včasih kdaj zafrkavajo, a vsem je mar za to, kako se počutijo drugi. Pa saj veš, tega moški ne pokažejo direktno. Saj si videl, kako ti je zadnjič Jernej prinesel kavo, ne da si karkoli rekel.« »Mhm ...« 


\section{KORAK UKREPANJA: POGOVARJANJE}

Če nam oseba pove, da si želi umreti, raziskujmo in skušajmo razumeti položaj.

V pogovoru poskušamo odkriti:

- kako pogoste so misli o smrti in samomoru,

- koliko si oseba želi umreti oz. kako resen samomorilni namen ima in

- ali že ima izdelan načrt za samomor.

Če imamo pri pridobivanju teh odgovorov težave z neposrednim pristopom, lahko prehajamo od manj direktnih k neposrednejšim vprašanjem. Misli, namen in načrtovanje težko opazimo iz vedenjskih znakov, zato moramo o tem povprašati.

\section{Kako pogosto}

razmišljaš o smrti? 0

tem, da te ne bi več

bilo?

Kako pogoste so

tvoje samomorilne

misli? Se to zgodi v

določenih situacijah?

Je to vsak mesec/

teden/tu in tam?

Večkrat na teden?

Vsak dan? Večkrat na

dan? Ves čas?

Kako dolgo že traja ta proces?
Kakšen je namen

tvojega razmišljanja

o samomoru?

Umreti?/Se

maščevati?/Se rešiti?

Imaš izdelano

zamisel, kako/kdajkje

bi naredil samomor?

Imaš že izbrano

metodo (vrv, tablete)?
Si se poškodoval

v zadnjem času/

zadnjih dveh tednih?

Si se resno

samopoškodoval v

zadnjem času?

Si poskušal

izpeljati samomor?

Kolikokrat? Kaj se je zgodilo? 


\section{IZ ŽIVLJENJA}

Ko je pogovor zastal, mi je bilo nelagodno in nisem bil prepričan, kako ga nadaljevati. Videl sem, da je še veliko nepovedanega. Zbral sem pogum in direktno nadaljeval.

»Tone, kako dolgo ti že hodijo te misli po glavi?« »Kakšen teden. No, pravzaprav od torka, ko sem dobil izvide. Saj ni tako hudo, samo vseeno so bili kaplja čez rob.«

„Pa si že načrtoval, kaj in kdaj bi naredil?« „Pa veš, da sem res ... Saj veš, vrv ... Ampak nisem pa še bil tako daleč, da bi si jo šel iskat. Ne, to pa še ne. Čeprav sem imel idejo, samo idejo." »Kaj pa, da bi si določil termin?« »No, tudi do tega še nisem prišel. Sem mislil, da se bom to kar spontano odločil.« 


\section{KORAK UKREPANJA: POGOVARJANJE}

Vprašati po samomorilnih težnjah je šele začetek, način nadaljevanja pogovora pa je odvisen od vsebine.

Če bo nerodno vam, se bo na tej točki začel umikati tudi sogovornik (morda s stavki, kot sta »saj ni tako zelo hudo« ali »saj se ni potrebno sekirati zame«). S takimi besedami se skuša oseba v stiski ogniti poglabljanju pogovora - ker ji je neprijetno, ne čuti pravega zaupanja ali ker ima občutek, da je neprijetno sogovorniku ali da mu je pogovor $v$ breme.

Imejte $v$ mislih, da želite na tej točki osebo predvsem spodbujati, da nadaljuje pripovedovanje. $S$ tem gradite občutek varnosti $v$ odnosu, dajete občutek sprejemanja in povezanosti z osebo, hkrati pa ji tudi pomagate izraziti in prepoznati razloge za samomor ter razloge za življenje.

\section{Razlogi za samomor}

Osebo prosimo, naj nam pojasni, katere stvari doživlja kot tako hude/tragične v svojem življenju, da jo to spodbuja k razmišljanju o samomoru. Taka vprašanja so morda posebno težka, saj nismo navajeni govoriti o tako intimnih in globokih temah. Lahko vprašamo:

\section{»Kaj so vse razlogi, zakaj bi rad umrl?«/»Kaj v zadnjem času je še posebej težko?"}

Poskusite osebo zgolj poslušati, brez takojšnjega dajanja nasvetov. Verjetno je oseba že preizkusila nekaj načinov soočanja, pa se niso izšli. Na tej točki pogovor raje spodbujajte tako, da poskušate razumeti, da so stvari, ki se osebi dogajajo, res težke - oz. jih tako doživlja. To ji v kratkih stavkih lahko tudi vedno znova poveste, npr.:

\section{»Razumem, to so res težke okoliščine. «}




\section{IZ ŽIVLJENJA}

»Tone, povej mi iz svojega zornega kota, zakaj ne želiš več živeti?«

»Ne vem, zdi se mi, da nikogar več nimam, da nimam ničesar, za kar bi živel. Trdno sem gradil, pa se mi je vse porušilo." »Če prav razumem, imaš občutek, da nikogar nimaš?«

»Mhm. Nič ne pretiravam. Ne mi zdaj reči, da imam sto prijateljev - sam veš, kako je to pri teh letih. Ni ljudi ...«

»Ja, ta občutek osamljenosti je res težek. Tudi sam ne vem, kako bi se počutil v takšni situaciji. Še kaj, zaradi česa nimaš več želje po življenju?« »Ma ne - to je to. Sej odnosi so najbolj pomembni.« 


\section{KORAK UKREPANJA: POGOVARJANJE}

\section{Razlogi za življenje}

Za nekoga, ki razmišlja o samomoru, je včasih težko govoriti o razlogih za življenje, saj jih ne najde zlahka - ob vprašanju, zakaj bi bilo vredno živeti, vas lahko hitro zavrne, češ da ni ničesar. $V$ tem primeru razmišljajte odprto in vprašajte npr.:

\section{Kdo ali kaj bi te najbolj pogrešal?}

Kaj je trenutno najboljši del tvojega življenja? Če bi, vsemu težkemu navkljub, moral izbrati nekaj, kaj bi to bilo?

Kakšne so tvoje dobre lastnosti ali tiste, na katere si lahko ponosen?

Kadar ljudje začnejo pripovedovati o razlogih za samomor, je v ozadju navadno tudi želja po življenju. Morda jo lažje najdejo, če ugotovijo, zakaj bi preživeli vsaj še ta dan/teden/mesec. Krajši časovni okvirji namreč zmanjšajo tesnobo.

Če znate, lahko poskusite kratko povzemati odgovore osebe. Vaši stavki pa naj bodo kratki, razumljivi, usmerjeni v dogajanje tukaj in zdaj. 


\section{IZ ŽIVLJENJA}

»Ampak, a lahko pomisliš, zakaj pa bi bilo po drugi strani vredno živeti?«

„Kaj jaz vem, če je sploh kaj. Ne vem. No, recimo za

tak pogovor. Zdaj mi je malo lažje..."

»Mhm ... tudi meni ... a pa še kaj?«

»Pa ne vem. A ti tu terapije z mano delaš? Saj ti

kar gre. No, sem se spomnil, da sem si vedno želel prehoditi pot od Litije do Čateža. Morda moram pa še to narediti ...«

»Pa glede odnosov in osamljenosti - a se ti zdi, da bi si glede tega lahko kako pomagal?«

»A misliš, da bi se malo več družil? Včasih se mi res ne da ... bi se pa moral malo prisiliti, saj potem je vedno fajn. « 


\section{KORAK UKREPANJA: POGOVARJANJE}

Med pogovarjanjem uporabljajte odprta vprašanja. Čeprav morda z vašega gledišča položaj sploh ni tako brezupen, se zavedajte, da ima oseba, ki razmišlja o samomoru, v svoji stiski zamegljen pogled na situacijo.

Taki situaciji rečemo tunelski vid - $v$ nasprotju z našim delovanjem, ko se dobro počutimo in znamo za svoje težave najti več načinov reševanja, je v kriznih situacijah lahko tako hudo, da je samomor videti kot edina rešitev. Samomor lahko predstavlja edino luč na koncu temnega tunela. S pogovorom pridobivamo čas, da se oseba prebije iz svojega tunela in ponovno zmore videti več možnih rešitev.

Morda ste bili že sami v podobnem položaju, kot je oseba v stiski, ali poznate koga, ki je preživel marsikaj hujšega. Vendar nikakor ni potrebno, da bi v tej situaciji osebi dajali napotke za reševanje situacije. Nasprotno - dajte ji le občutek sprejemanja in tega, da vam pogovor ni odveč ali v breme. Preko tega bosta lahko skupaj iskala rešitve. 


\section{IZ ŽIVLJENJA}

Pri sebi sem razmišljal, da Tone ni edini, ki ima takšne okoliščine. Saj tudi jaz nimam ne vem koliko prijateljev! Najraje bi mu povedal kakšno krepko, a sem se ugriznil $v$ jezik.

Ni mi dalo miru, zato sem vseeno še enkrat vprašal. »Tone, kako to, da te je vse to iztirilo do te mere? Je načelo tvojo samozavest?«

»Saj še sam ne vem, zakaj sem padel v to brezno. Nisem se zavedal, kdaj se je situacija začela tako slabšati. Saj vem, nisem edini, ki nima idealne zgodbe. Zdaj začenjam videti, da je še kakšna rešitev za to situacijo ... « 


\section{KORAK UKREPANJA: ODNOS ZAUPANJA}

Ko enkrat razumemo ozadje, ugotovimo resnost samomorilnega stiske in vzpostavimo pristen odnos, dober stik z osebo v stiski (prav ta je ključen in največkrat rešuje življenja), načrtujemo nadaljnje korake.

\section{Pristen odnos, stik z drugo osebo največkrat rešuje življenja.}

\section{Osebo s tem prepričamo za življenje.}

Zanimati nas mora počutje osebe po koncu pogovora. Preveriti moramo, ali se je želja po smrti spremenila. Sprememba lahko preseneti tudi osebo v stiski, saj ima pogosto občutek, da je nenehno težko in da si ves čas želi končati življenje.

Če je oseba vsaj malo razbremenjena, se pogovarjajmo o načrtovanju tistega dne in naslednjih korakov za okrevanje.

\section{Uporabna tehnika: obljuba za življenje}

Osebo lahko tudi prosimo, da nam obljubi, da si do naslednjega dne, ko bomo spet v stiku z njo, ne bo ničesar naredila. Temu rečemo obljuba za življenje. Časovni okvir obljube za življenje mora biti kratek, saj je sicer oseba ne more iskreno zagotoviti. Mi pa moramo obvezno držati zavezo in osebo v dogovorjenem času ponovno srečati oz. kontaktirati. 


\section{IZ ŽIVLJENJA}

»Tone, kako si zdaj?»

»Težko je govoriti o vsem tem. Niti nisem vedel, da sem že tako zabredel, dokler nisem zdaj vsega povedal. Drugače zveni vse. Boljše sem zdaj.« »Kako pa je z željo po smrti?« »Hmm ... nisem niti opazil, ampak zdaj se mi zdi, da imam malo več volje za življenje.« »A res?"

»Ja, nisem si mislil, da lahko tak pogovor naredi razliko. Saj veš, jaz nisem med tistimi, ki o sebi povedo veliko osebnega." »Mi lahko obljubiš, da si do jutri ne boš nič naredil? Res bi želel to obljubo ..." »Lahko ti obljubim! Zares, hvala ti.« »Jutri zjutraj se oglasim pri tebi, da vidim, kako si.« 


\section{KORAK UKREPANJA: NAPOTITEV IN KROG PODPORE}

Osebi, ki razmišlja o samomoru, je o njeni stiski težko povedati drugim. Kljub temu se z njo dogovorite (ali vsaj poskušajte), da za težave pove tudi drugim iz svoje socialne mreže (lahko ponudite, da ji boste pri tem pomagali).

Skupaj zgradite krog podpore za osebo.

Prav tako je ključno, da oseba v stiski čim prej dobi ustrezno strokovno pomoč, zato ji pomagajte poiskati strokovnjake. Seznami so na voljo na koncu zloženke. 


\section{IZ ŽIVLJENJA}

»Sam ne moreš tako ostati. Komu bi še lahko povedal, kako si?«

»Zdaj razmišljam, morda bom šel k svoji zdravnici, da se malo izpovem še njej. Je kar fajn ženska, morda mi bo lahko pomagala."

»To se mi zdi dobra ideja! A boš šel kar jutri?« »Ja, bom šel takoj zjutraj.«

»Komu bi še lahko skupaj povedala za to situacijo? Če ti je OK, bi se kar jaz oglasil pri delovodji. Ne bom šel v podrobnosti, ampak vseeno bom povedal, da se ne počutiš dobro. Bo bolj razumel, zakaj se obnašaš drugače." »Oh, a si nor? Kaj pa si bo mislil o meni ... No, ampak verjetno je že itak nekaj opazil. Torej, če mislišs, da me zaradi tega ne bo iz službe vrgel, potem OK ...« »Mislim, da bo razumel. Boš povedal doma?« »Obrnil se bom še na sestro. Ona je za take reči.« »No, saj imaš kar nekaj ljudi okoli sebe ..." »Ja, morda pa res več kot se mi je sprva zdelo ..." 


\section{NUJNI PRIMERI}

Če je oseba res zelo akutno ogrožena (torej neprestano razmišlja o samomoru), je nikakor ne puščajte same. Poskušajte jo prepričati, da skupaj poiščeta nujno medicinsko oz. psihiatrično pomoč.

Po Zakonu o duševnem zdravju pa lahko osebo, ki je akutno nevarna sebi, hospitaliziramo tudi proti njeni volji.

V skrajnem primeru torej pokličite na številki $\mathbf{1 1 3}$ in $\mathbf{1 1 2}$.

Policija v primeru samomorilnih groženj na kraj dogodka pošlje patruljo. Poleg policistov se v delo vključi tudi dežurni zdravnik, ki oceni stanje.

$\checkmark$ nekaterih primerih se $v$ reševanje situacije vključijo tudi policijski pogajalec ali pa drugi sistemi zaščite in reševanja. 


\section{TELEFONSKI KLIC}

Lahko se zgodi, da vas bo nekdo poklical po telefonu in vam zaupal, da je $v$ hudi stiski ter trenutno načrtuje samomor. Morda obenem grozi, da bo vaša prekinitev zveze (da bi poklicali pomoč) sprožilec smrti.

Take situacije so zelo težke in zanje pride $v$ poštev predvsem 3. korak, torej pogovarjanje. Poleg navedenih smernic poskušamo osebo napeljati, da resnično čim več govori. $Z$ vprašanji se osredotočimo na opisovanje doživljanja in okoliščin:

- oseba lahko opisuje svoja občutja (npr. kakšne okoliščine so jo pripeljale do tega trenutka)

- ali pa poroča o zaznavanju okolice, torej kaj vidi, sliši, vonja, čuti v tem trenutku.

Pri tem spodbujamo opisovanje nevtralnih dražljajev.

V primerih, ko nam oseba ne želi povedati svoje lokacije, bo imelo opisovanje tega, kar vidi, dva učinka: pozornost bo začasno usmerila izven sebe in se morda nekoliko oddaljila od intenzivnih čustev, iz opisa pa boste morda tudi prepoznali njeno lokacijo.

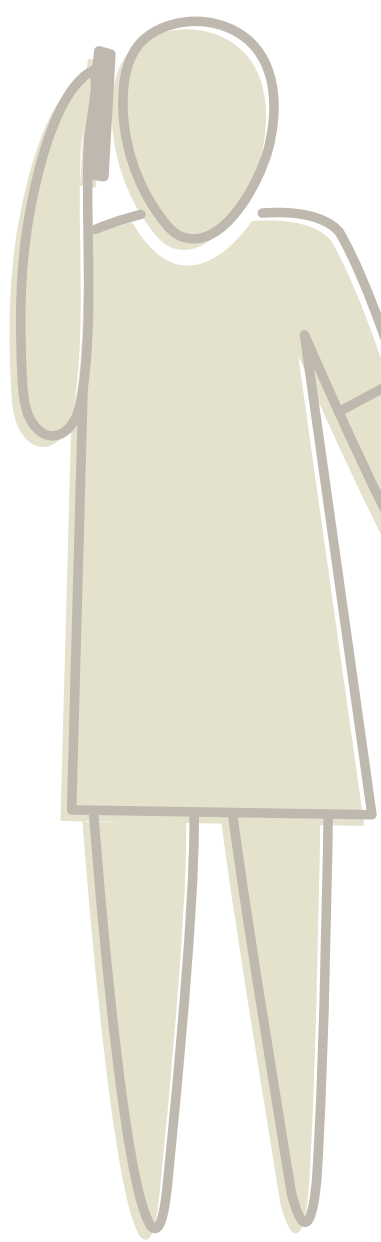

Vaša vprašanja naj bodo raziskovalna in odprta. Izrazite skrb za varnost osebe in jo spodbujajte, naj pride k vam ali h komu drugemu po pomoč. 


\section{DOŽIVLJANJE OB NUDENJU \\ PODPORE}

Pogovor o samomoru v nas sproža široko paleto čustev.

Lahko nas je strah in dvomimo, da bomo kos takšnemu pogovoru oz. se bojimo, da si oseba res ne bo česa naredila. Nekateri so jezni na osebo, ki razmišlja o samomoru, saj se jim zdi, da položaj vendarle ni tako brezupen ali da bi že prej lahko poiskala pomoč. Pogosti pa so tudi občutki krivde, da nismo osebi že prej pomagali, ali občutki žalosti, da je situacija tako težka.

Paleta našega doživljanja je torej raznovrstna. Bolj kot to, da bi morali negativna čustva odmisliti, je pomembno, da jih razumemo. Te situacije niso vsakdanje, zato je normalno, da v vsakem od nas sprožajo močne reakcije. Pomembno je, da čustva toliko obvladamo, da nas ne ovirajo pri nudenju podpore.

Nekaterim za odločitev za ukrepanje pomaga občutek poguma, da bodo zmogli pomagati. Kadar nam oseba zaupa, pa lahko občutimo tudi hvaležnost, zadovoljstvo in olajšanje. 


\section{SKRB ZASE PRI PODPORI DRUGIM}

Za uspešno pomoč drugemu moramo nujno skrbeti zase.

Po intervenciji ob samomorilnih mislih zaupajte situacijo nekomu, ki vam predstavlja varno in podporno osebo. Zabeležite si: koga bi v takem primeru poklicali?

Razbremenite se s športom, hobiji, pripravljanjem obroka ali drugo dejavnostjo in poskusite pri tem čimbolj osredotočiti pozornost na dejavnost, ki jo opravljate $v$ danem trenutku. Zabeležite si: s katero aktivnostjo si »polnite baterije«? 


\section{KAM PO POMOČ?}

Če čutite hudo duševno stisko ali imate samomorilne misli, poiščite strokovno pomoč $v$ organizacijah, ki nudijo neposredno pomoč. Lahko se obrnete na svojega osebnega zdravnika, ki vas lahko napoti do specialistične obravnave (znotraj zdravstva h kliničnemu psihologu ali k psihiatru, podporo pa lahko najdete tudi pri psihoterapevtih). Za mlade so na voljo tudi šolske svetovalne službe.

\section{Pomoč je na voljo še na:}

112 - Center za obveščanje (za takojšnjo nujno pomoč)

113 - Policija

116123 - Zaupni telefon Samarijan in Sopotnik (24h/dan)

116111 - TOM - telefon za otroke in mladostnike (vsak dan med 12. in 20. uro)

015209900 - Klic v duševni stiski (vsak dan med 19. in 7. uro)

031233211 - Ženska svetovalnica - krizni center (24h/dan)

Prav tako so na voljo brezplačna svetovanja v Psiholoških svetovalnicah Posvet po celi Sloveniji: 031704 707, info@posvet.org

Pomoč za mlade je na voljo tudi na spletni strani »To sem jaz« (www.tosemjaz.net), informacije pa tudi na www.e-tom.si in za odrasle na www.nebojse. si.

Na spletni strani »Živ? Živ! Postaja za razumevanje samomora« so na voljo informacije za odrasle v stiski, za tiste, ki želijo pomagati, za žalujoče in za medije (www.zivziv.si). 


\section{UPAD SAMOMORILNEGA VEDENJA}

V osemdesetih je bila Slovenija glede na višino količnika samomora med prvimi tremi državami na svetu. Od leta 2000 statistični podatki pri nas kažejo na trend upadanja števila samomorov. Če je nekoč zaradi samomora umrlo tudi do 700 ljudi letno, se trenutno številke gibajo okoli 400 smrti.

Podoben trend se kaže tudi v nekaterih drugih zahodnoevropskih državah. $\mathrm{K}$ upadu prispeva veliko dejavnikov: od boljše kvalitete življenja, zdravljenja in ukrepanja pri težavah v duševnem zdravju do omejevanja dostopnosti alkohola, pojava novih tehnologij, ki povezujejo ljudi med seboj, pa tudi spremenjenih stališč do iskanja pomoči v stiski.

Prav tako je danes na voljo več preventivnih programov in ozaveščanja o tem problemu. Predvsem ob svetovnem dnevu preprečevanja samomora, ki ga vsako leto obeležujemo 10. septembra, o samomoru govorimo več.

Tisti, ki so bili v samomorilni stiski, kot najpomembnejši dejavnik, ki jim je pomagal iz težke situacije, navedejo iskreno podporo in skrb drugih ljudi.

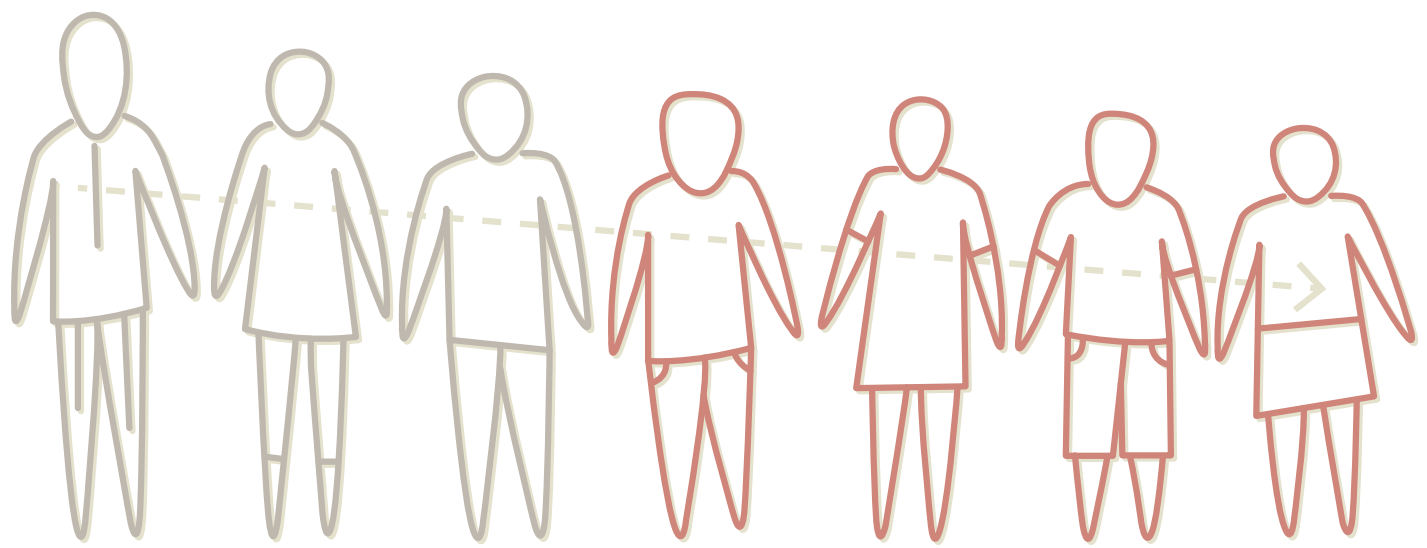




\section{IZ ŽIVLJENJA}

Bil sem v stiski.

Opazil si me. Zbral si pogum in me nagovoril.

Verjetno ne veš, a rešil si mi življenje.

Tvoj pogovor je bil za mojo dušo kot kozarec vode žejnemu - potešil je mojo osamljenost, dal mi je moč za naslednje življenjske korake.

Hvala,

Tone 


\section{POJASNILO ZGODBE IZ ŽIVLJENJA}

Tonetova zgodba je izmišljena, čeprav resnična.

Resnična je zato, ker temelji na nešteto zgodbah, ki sem jih $v$ času dela na področju preprečevanja samomora slišala, doživela in o njih govorila. To so zgodbe iz mest in vasi, zgodbe tistih z višjimi in tistih z nižjimi prihodki, žensk in moških, mlajših in starejših oseb, zgodbe vseh nas.

Pogovor s Tonetom je le primer in služi kot ponazoritev teorije v praksi. Vzemite ga kot vodilo, ki ga prilagodite svojim okoliščinam. Z iskreno pomočjo boste pomagali bolj, kot si lahko mislite.

Resnične so tudi tiste zgodbe, kjer se Tonetova pot konča drugače - s samomorom. Žalovanju je namenjena druga knjižica. 
Slovenski center za raziskovanje samomora
I A M

$I_{\text {NSTT }}^{I_{S T I T T}}$
REPUBLIKA SLOVENIJA

MINISTRSTVO ZA ZDRAVJE 